ABDIMAS: Jurnal Pengabdian Masyarakat Universitas Merdeka Malang
Vol.7(1) February 2022, 103-112
i-ISSN: 2721-138X e-ISSN: 2548-7159
Uttp://jurnal.unmer.ac.id/index.php/jpkm

\title{
Utilization of Barracuda Fish (Sphyraena barracuda) as fish nugget in Sorkam District, Central Tapanuli
}

\author{
Pemanfaatan Ikan Barakuda (Sphyraena barracuda) sebagai nugget ikan di \\ Kecamatan Sorkam, Tapanuli Tengah \\ Rosmasita Rosmasita1, Tengku Muhammad Ghazali², Dian Fitria Manurung², \\ Emma Suri Yanti Siregar ${ }^{3}$, Irwan Limbong ${ }^{1}$, Filla Simanjuntak², Hensamuel Situmeang ${ }^{1}$ \\ 'Departemen Teknologi Penangkapan Ikan, '2Departemen Akuakultur, ${ }^{3}$ Departemen Sosial Ekonomi Perikanan, \\ Sekolah Tinggi Perikanan dan Kelautan Matauli \\ Jl. KH. Dewantara No.1, Sibuluan Indah, Tapanuli Tengah, 22538, Indonesia
}

\begin{abstract}
ARTICLE INFO:
ABSTRACT

Received: 2020-11-02

Revised: 2021-04-20

Accepted: 2021-09-23

Barracuda fish in the Central Tapanuli region is known as Teter fish (Sphyraena barracuda) which is still relatively cheap and easy to get throughout the year. Teter fish has many health benefits, but not everyone likes this fish. Based on this, various processed forms are needed in order to attract other people to continue consuming tethered fish. One of these processed forms is fish nuggets. The purpose of this community service activity is to provide education to the community, especially mothers in the Indonesian Family Welfare Guidance Program or PKK in Sorkam District, Central Tapanuli Regency about the use of teter fish meat as a processed material for making fish nuggets. The method used

Keywords:

Fish nugget, Sorkam, Sphyraena barracuda, Tapanuli Tengah is the delivery of material and direct practice in making fish nuggets. The result of this community service activity is the ability of PKK women to make processed fish nuggets and package the product properly. In the future, fish nuggets can increase family income and are sold as a typical food of Central Tapanuli.
\end{abstract}

(C) 2022 Abdimas: Jurnal Pengabdian Masyarakat Universitas Merdeka Malang This is an open access article distributed under the CC BY-SA 4.0 license (https://creativecommons.org/licenses/by-sa/4.0/)

How to cite: Rosmasita, R., Ghazali, T. M., Manurung, D. F., Siregar, E. S. Y., Limbong, I., Simanjuntak, F., \& Situmeang, H. (2021). Utilization of Barracuda Fish (Sphyraena barracuda) as fish nugget in Sorkam District, Central Tapanuli. Abdimas: Jurnal Pengabdian Masyarakat Universitas Merdeka Malang, 7(1), 103-112.

https://doi.org/10.26905/abdimas.v7i1.5337

\section{PENDAHULUAN}

Ikan Barakuda atau Alu-alu di wilayah Tapanuli Tengah dikenal dengan sebutan Ikan Teter. Potensi Barakuda (Sphyraena barracuda) di Tapanuli Tengah yaitu 984,3 ton pada tahun 2014 dan 844 ton pada tahun 2015 dengan harga jual segar Rp15.000/kg (Dinas Perikanan dan Kelautan Tapanuli Tengah, 2021). Berdasarkan survei ke pasar yang ada di Tapanuli Tengah khususnya di Tempat Pendaratan Ikan Kecamatan Sorkam harga Ikan Teter berkisar Rp15.000-Rp20.000. Berdasarkan data tersebut ikan ini masih tergolong murah dan mudah diperoleh di sepanjang tahun. 
ABDIMAS: Jurnal Pengabdian Masyarakat Universitas Merdeka Malang

Volume 7, No 1, February 2022: 103-112

Ikan Teter memiliki khasiat untuk kesehatan, seperti mengandung Vitamin B2, membantu memperlancar metabolisme, mengobati anxiety disorder, mendorong pembentukan hemoglobin, menyembuhkan radang kulit, meningkatkan vitalitas pria, baik bagi penderita diabetes, mencegah penyakit jantung, baik untuk pembuluh darah, baik bagi kesehatan mata, menjaga kesehatan paru-paru, mencegah depresi, baik bagi kesehatan kulit, membantu melindungi terjadinya peradangan usus, meningkatkan kemampuan otak, meredakan gejala rheumatoid arthritis dan mengandung nutrien penting bagi tubuh (Fatmawati et al., 2018; Direktorat Jenderal Perikanan Tangkap, 2003).

Menurut Lukman et al. (2009), nugget adalah produk daging direstrukrisasi dengan adonan dan pelapis untuk mempertahankan kualitas. Nugget adalah suatu bentuk produk olahan daging yang terbuat dari daging giling yang dicetak dalam bentuk potongan empat persegi dan dilapisi dengan tepung berbumbu (battered and braded). Nugget juga dikenal sebagai makanan beku siap saji sehingga masyarakat modern saat ini sangat menggemari karena kepraktisan dalam mengkonsumsi nugget. Proses pengolahan nugget pada umumnya meliputi penggilingan daging, pencampuran bumbu, pengukusan, pencetakan, pelumuran tepung, dan pembekuan (Genesa et al., 2018; Fatmawati et al., 2018; If'all et al., 2018; Rijal, 2016; Rieuwpassa, 2016; Utiarahman et al., 2013).

Pemanfaatan daging ikan sebagai bahan olahan sudah banyak dilakukan sebelumnya, seperti: (1) Genesa et al. (2018) memanfaatkan Ikan Cakalang (Katsuwonus pelamis l) sebagai bahan pembuatan nugget yang dicampur dengan ekstrak buah mengkudu; (2) Aziza et al. (2015) memanfaatkan Ikan Tongkol (Euthynnus affinis) sebagai bahan pembuatan bakso; (3) Yulianti \& Mutia (2018) memanfaatkan Ikan Gabus (Ophiocephalus striatus) sebagai bahan pembuatan nugget; (4) If'all et al. (2018) memanfaatkan Ikan Tuna (Thunnus sp) sebagai bahan pembuatan nugget. Ikan Alu-alu juga dijadikan sebagai bahan olahan seperti surimi dan bakso ikan (Purwandari et al., 2014), nugget di wilayah Kendari (Sali et al., 2020), namun untuk pemanfaatannya sebagai bahan olahan nugget di wilayah Kecamatan Sorkam belum pernah dilaksanakan.

Organisasi PKK (Pembinaan Kesejahteraan Keluarga) merupakan suatu organisasi yang berupaya tidak hanya mendidik perempuan, melainkan membina dan membangun keluarga di bidang mental spiritual dan fisik material serta peningkatan mutu pangan, sandang, papan, kesehatan, dan lingkungan hidup (Shalfiah, 2013). PkM ini melibatkan ibu-ibu PKK di Kecamatan Sorkam dikarenakan kebanyakan latar belakang dari pekerjaan suami mereka adalah nelayan. Dengan adanya kegiatan ini diharapkan ibuibu PKK dapat mengolah hasil perikanan dan kedepannya bisa dijadikan sebagai ide dalam membuat usaha yang dapat meningkatkan penghasilan keluarga.

Sekolah Tinggi Perikanan dan Kelautan Matauli (STPK Matauli) melalui Pusat Penelitian dan Pengabdian kepada Masyarakat (LPPM) telah menetapkan kegiatan Pengabdian kepada Masyarakat (PkM) yang wajib dilaksanakan sebagai implementasi salah satu dari Tri Dharma Perguruan Tinggi. Kegiatan PkM ini bertujuan memberikan edukasi kepada masyarakat khususnya ibu-ibu PKK di Kecamatan Sorkam, Kabupaten Tapanuli Tengah tentang pemanfaatan daging Ikan Teter sebagai bahan olahan untuk pembuatan Nugget ikan. Berdasarkan latar belakang masalah yang telah dijabarkan, maka permasalahannya dapat diidentifikasi pada Gambar 1.

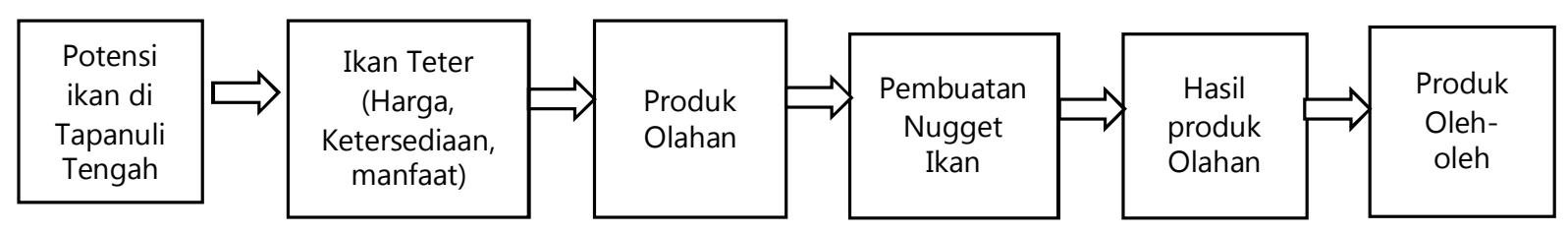

Gambar 1. Kerangka solusi pemecahan masalah 
Utilization of Barracuda Fish (Sphyraena barracuda) as fish nugget in Sorkam District, Central Tapanuli

Rosmasita, Tengku Muhammad Ghazali, Dian Fitria Manurung, Emma Suri Yanti Siregar, Irwan Limbong1, Filla Simanjuntak, Hensamuel Situmeang

\section{METODE}

Kegiatan PkM ini dilaksanakan pada tanggal 12 Desember 2020 di Aula Kecamatan Sorkam, Kabupaten Tapanuli Tengah dengan melibatkan ibu-ibu PKK Kecamatan Sorkam dengan jumlah 25 orang yang berasal dari beberapa desa di Kecamatan Sorkam sebagai peserta pada kegiatan ini. Jumlah peserta dibatasi dikarenakan kegiatan PkM ini dilaksanakan pada masa pandemi COVID-19 dan harus mematuhi protokol kesehatan. Metode yang digunakan yaitu dengan cara penyampaian materi dan praktik langsung dalam pembuatan nugget ikan. Untuk pelaksanaan kegiatan dilakukan dengan menggunakan rangkaian tahapan yaitu: (1) Pembagian tugas. Pertemuan tim PkM untuk mendiskusikan materi kegiatan yang akan dilaksanakan dan pembagian tugas antar tim pelaksana, menyiapkan administrasi, dan teknis kegiatan di lapangan; (2) Survei lokasi. Kegiatan survei dan koordinasi dengan Camat dan ketua PKK di Kecamatan Sorkam, Kabupaten Tapanuli Tengah untuk pengadaan kegiatan pengabdian kepada masyarakat; (3) Mempersiapkan materi, bahan, dan alat. Sebelum pelaksanaan kegiatan pengabdian kepada masyarakat segala keperluan dipersiapkan sebaik baiknya. Persiapan dimulai dengan persiapan materi presentasi, bahan untuk pembuatan nugget dan alat-alat yang digunakan dalam pembuatan nugget; (4) Presentasi dan tanya jawab. Presentasi materi tentang manfaat Ikan Teter, tujuan kegiatan pengabdian kepada masyarakat, materi pembuatan nugget ikan serta proses tanya jawab; (5) Praktik. Setelah dilaksanakannya proses penyampaian materi dan proses tanya jawab, selanjutnya dilakukan praktik langsung pembuatan Nugget ikan. Mulai dari proses surimi ikan sampai ke tahap pengemasan produk Nugget Ikan agar memiliki daya simpan dan dapat dinikmati dalam waktu yang lama; (6) Modul. Penggunaan modul dalam pelatihan ini, dimaksudkan untuk dijadikan sebagai bahan acuan peserta untuk pembuatan Nugget Ikan, mulai dari bahan, alat dan proses pembuatan Nugget Ikan Teter.

Kemudian dilakukan rancangan evaluasi Kegiatan pengabdian kepada masyarakat yang dapat dilihat ketercapaiannya dengan cara: (1) Keberhasilan dari pelaksanaan kegiatan adalah dengan melaksanakan kegiatan sesuai dengan waktu dan target peserta pelaksanaan kegiatan PkM yang telah ditentukan sehingga perlu adanya kerjasama yang baik antara pelaksana dengan peserta; (2) Keberhasilan dari pihak peserta antara lain adalah peserta mampu mempraktikkan atau menerapkan secara individu dan mengetahui metode yang digunakan untuk membuat Nugget Ikan dari proses awal hingga proses pengemasan; (3) Keberhasilan dari pihak pelaksana adalah mampu memberikan penjelasan serta bantuan yang dapat membantu peserta yang mengalami kesulitan dalam melakukan praktik membuat nugget. Selain itu, keberhasilan tim pelaksana juga dapat diukur dari pelayanan yang baik dalam melakukan komunikasi pada saat pelaksanaan kegiatan.

\section{HASIL DAN PEMBAHASAN}

Proses pelaksanaan kegiatan PkM ini diawali dengan pembukaan acara kegiatan PkM, doa, kata sambutan, presentasi untuk penyampaian materi, tanya jawab dan diskusi, pelatihan pembuatan Nugget Ikan, proses pengemasan Nugget Ikan dan Penutupan. Pembukaan kegiatan PkM dipandu oleh Master Ceremony (MC) pelaksana kegiatan. MC membacakan susunan acara kepada peserta dan memperkenalkan tim PkM yang mengadakan kegiatan. MC berperan aktif dalam manajemen pelaksanaan kegiatan PkM. Adapun acara pembukaan disajikan pada Gambar 2. Sebelum memasuki acara inti kegiatan pengabdian kepada masyarakat, maka semua pelaksana kegiatan dan peserta berdoa agar kegiatan yang akan dilaksanakan dapat berjalan dengan baik. Kemudian sesi pemberian kata sambutan. Kata sambutan terdiri dari dua belah pihak, yaitu pihak pertama dari pelaksana kegiatan PkM yang dibawakan langsung oleh ketua Yayasan Maju Tapian Matauli (Yayasan MATAULI) dan pihak kedua oleh 
ABDIMAS: Jurnal Pengabdian Masyarakat Universitas Merdeka Malang Volume 7, No 1, February 2022: 103-112

ketua PKK di Kecamatan Sorkam, Kabupaten Tapanuli Tengah. Kata sambutan berfungsi agar peserta maupun pelaksana kegiatan PkM merasa dihormati dan dianggap dalam kegiatan yang dilaksanakan. Adapun kegiatan kata sambutan disajikan pada Gambar 3.
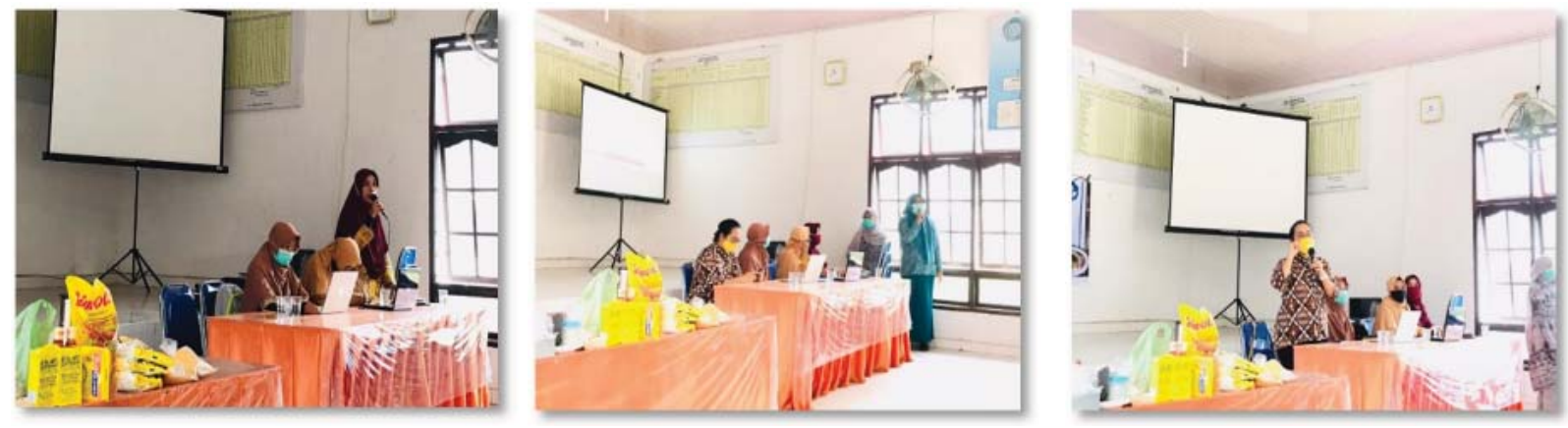

Gambar 2. Pembukaan oleh MC

Gambar 3. Proses kata sambutan

Selanjutnya tahap presentasi. Pada tahap ini, peserta diberikan informasi mengenai kelebihan mengkonsumsi ikan, manfaat Ikan Teter, keunggulan Ikan Teter dibandingkan dengan ikan lainnya, produk olahan yang dapat dihasilkan dari Ikan Teter, peluang bisnis dengan pemanfaatan daging Ikan Teter. Media yang digunakan untuk memudahkan proses penyampaian materi yaitu dengan Power Point dan pembagian buku resep untuk pembuatan Nugget Ikan, serta menyajikan langsung produk Nugget Ikan Teter yang sebelum pelaksanaan kegiatan telah disiapkan oleh tim PkM. Adapun kegiatan penyampaian materi disajikan pada Gambar 4.

Selanjutnya tahap tanya jawab. Proses tanya jawab bertujuan untuk memberikan informasi lebih kepada peserta yang belum paham atau ingin mengetahui lebih bagaimana memanfaatkan daging Ikan Teter untuk dijadikan bahan pembuatan Nugget Ikan. Peserta sangat antusias dalam proses tanya jawab yang dilaksanakan. Adapun proses tanya jawab disajikan pada Gambar 5.
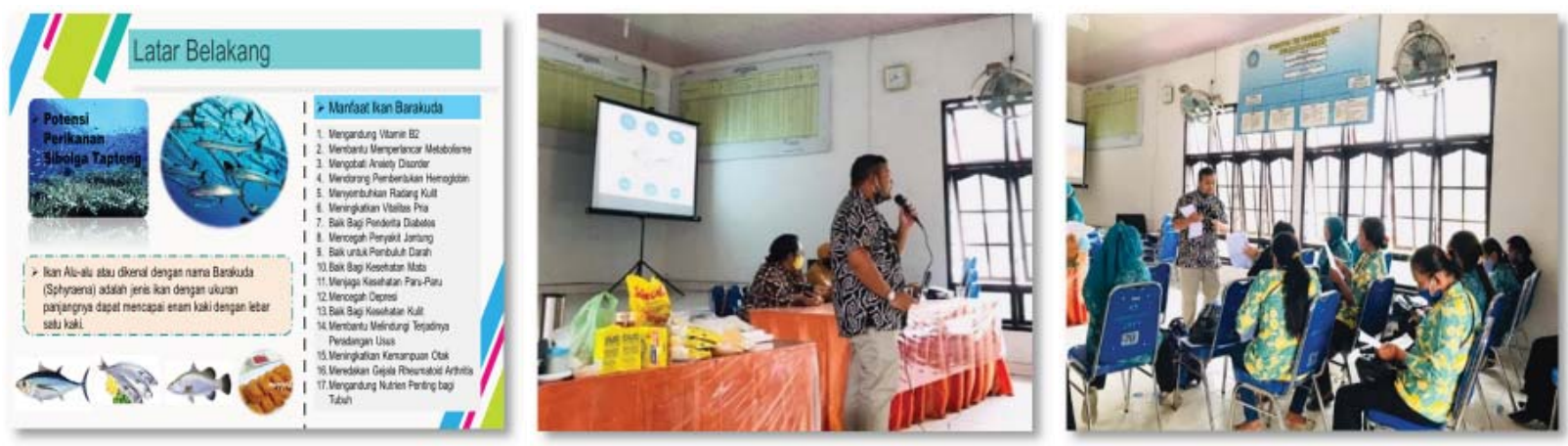

Gambar 4. Penyampaian materi

Gambar 5. Proses tanya jawab

Selanjutnya adalah pelatihan pembuatan Nugget Ikan. Adapun bahan dan alat yang digunakan saat pelatihan pembuatan Nugget Ikan disajikan pada Tabel 1 dan Tabel 2. 
Utilization of Barracuda Fish (Sphyraena barracuda) as fish nugget in Sorkam District, Central Tapanuli

Rosmasita, Tengku Muhammad Ghazali, Dian Fitria Manurung, Emma Suri Yanti Siregar, Irwan Limbong1, Filla Simanjuntak, Hensamuel Situmeang

Tabel 1. Bahan untuk membuat nugget ikan

\begin{tabular}{|c|c|}
\hline Bahan & Ukuran \\
\hline Ikan Teter & $2 \mathrm{Kg}$ \\
\hline Bawang Merah & 2 Ons \\
\hline Bawang Putih & 2 Ons \\
\hline Jahe & 1 Ons \\
\hline Tepung Tapioka & $1 \mathrm{Kg}$ \\
\hline Telur & 5 Butir \\
\hline Garam & $2 \mathrm{Sdm}$ \\
\hline Gula & $2 \mathrm{Sdm}$ \\
\hline Es & 2 Buah \\
\hline Minyak Goreng & $1 \mathrm{~L}$ \\
\hline Penyedap Rasa & 1 Bungkus \\
\hline Jeruk Nipis & 2 Buah \\
\hline Tepung Panir & $1 \mathrm{Kg}$ \\
\hline Tepung Maizena & 2 Kotak \\
\hline
\end{tabular}

Adapun langkah-langkah dalam pembuatan nugget ikan adalah sebagai berikut: (1) Bersihkan ikan dan pisahkan daging dengan tulang dan kulit (fillet); (2) Rendam dengan jeruk nipis secukupnya; (2) Rendam dengan air es; (3) Haluskan daging dengan air es; (4) Haluskan bawang merah, bawang putih dan jahe secara terpisah; (5) Masukkan daging + bumbu halus + garam + gula + penyedap + minyak goreng (secukupnya) aduk secara merata; (6) Masukkan tepung secara perlahan; (7) Setelah kalis masukkan kuning telur; (8) Panaskan dandang yang sudah berisi air dan minyak; (9) Masukkan adonan ke dalam loyang yang sudah diberi minyak; (10) Setelah adonan sudah diletakkan dalam loyang dan ratakan; (11) Kukus adonan nugget selama 20 menit; (12) Setelah masak dinginkan, kemudian potong adonan sesuai selera; (13) Masukan potong nugget ke dalam tepung maizena yang sudah diberi air; (14) Masukkan ke dalam putih telur; (15) Masukkan adonan ke tepung panir secara merata; dan (16) Goreng nugget di api kecil.

Tabel 2. Alat untuk membuat Nugget Ikan

\begin{tabular}{lc}
\hline \multicolumn{1}{c}{ Alat } & Jumlah (pcs) \\
\hline Dandang Pengukus & 1 \\
Kompor Gas & 1 \\
Gas & 1 \\
Blender & 1 \\
Plastik Wrap & 1 \\
Baskom & 2 \\
Spatula & 2 \\
Penyaring & 1 \\
Sendok & 4 \\
Piring Wadah & 6 \\
Loyang Petak & 3 \\
Wajan & 1 \\
\hline
\end{tabular}


ABDIMAS: Jurnal Pengabdian Masyarakat Universitas Merdeka Malang

Volume 7, No 1, February 2022: 103-112

Proses kegiatan pelatihan pembuatan nugget dengan ibu-ibu PKK di Kecamatan Sorkam, Kabupaten Tapanuli Tengah berjalan dengan baik. Kegiatan ini disambut dengan antusias oleh ibu-ibu PKK. Ada beberapa tahapan dalam proses pembuatan Nugget Ikan Teter.

\section{Pengenalan bahan dan alat}

Sebelum proses pembuatan Nugget Ikan Teter dilakukan, terlebih dahulu dijelaskan bahan dan alat yang akan digunakan dalam proses pembuatan Nugget Ikan Teter. Hal ini bertujuan agar ibu-ibu PKK dapat memahami bahan dan alat yang digunakan dan ke depannya dapat menerapkan proses pembuatan nugget dengan membeli bahan dan alat yang dibutuhkan. Adapun proses pengenalan bahan dan alat disajikan pada Gambar 6.

\section{Membuat surimi}

Surimi merupakan produk semi basah (konsentrat protein ikan) yang dihasilkan dengan cara melakukan pencucian daging ikan secara berulang hingga didapatkan protein larut garam berupa myofibril (Laksono et al., 2019; Tina et al., 2010; Wahdan, 2010). Adapun hasil surimi Ikan Teter disajikan pada Gambar 7.

\section{Pembuatan adonan}

Proses pembuatan adonan dilakukan berdasarkan petunjuk yang telah dijelaskan baik secara langsung maupun yang tertera di buku resep yang telah dibagikan. Adapun proses pembuatan adonan disajikan pada Gambar 8.
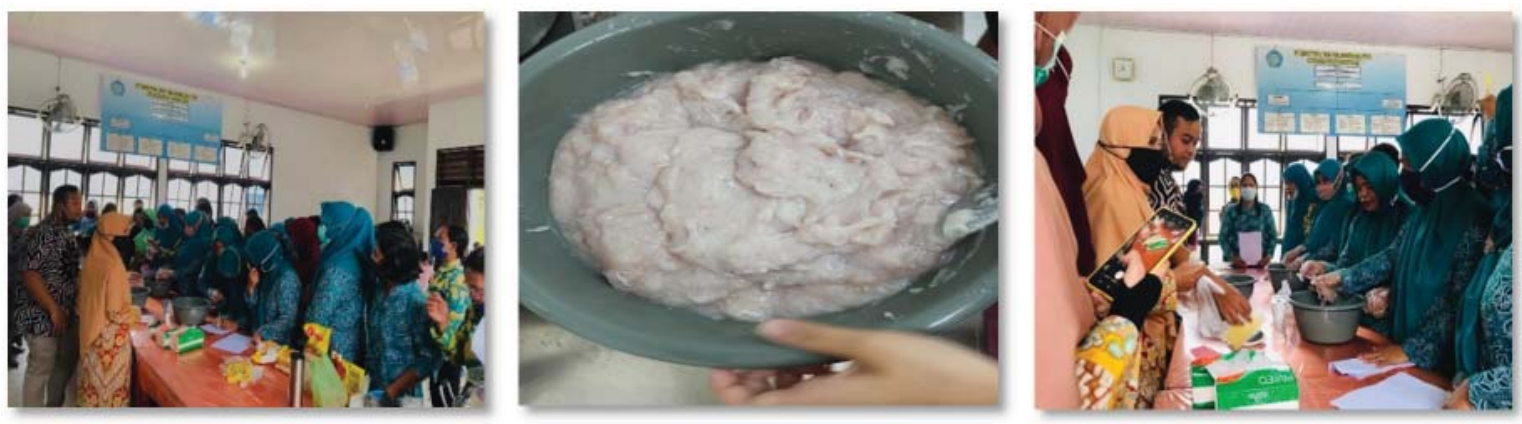

Gambar 6. Pengenalan bahan dan alat

Gambar 7. Hasil surimi Ikan Teter

Gambar 8. Proses pembuatan adonan

\section{Membuat adonan ke loyang dan proses pengukusan}

Setelah adonan selesai dibuat, selanjutnya adonan diletakkan di dalam loyang. Sebelum adonan diletakkan terlebih dahulu loyang dioles minyak secukupnya agar adonan tidak lengket. Proses pengukusan dilakukan pada dandang yang terlebih dahulu dipanaskan. Adonan dimasukkan ke dalam dandang, dandang ditutup rapat kemudian di tunggu 15-20 menit hingga adonan matang. Adapun proses membuat adonan ke loyang dan proses pengukusan disajikan pada Gambar 9.

\section{Proses akhir pembuatan nugget}

Adonan nugget yang telah matang, selanjutnya didiamkan hingga dingin, kemudian dipotong dengan ukuran sesuai dengan selera. Potongan-potongan tersebut kemudian dilumuri dengan tepung maizena, putih telur, dan kemudian dibalut dengan tepung panir. Proses akhir pembuatan Nugget Ikan 

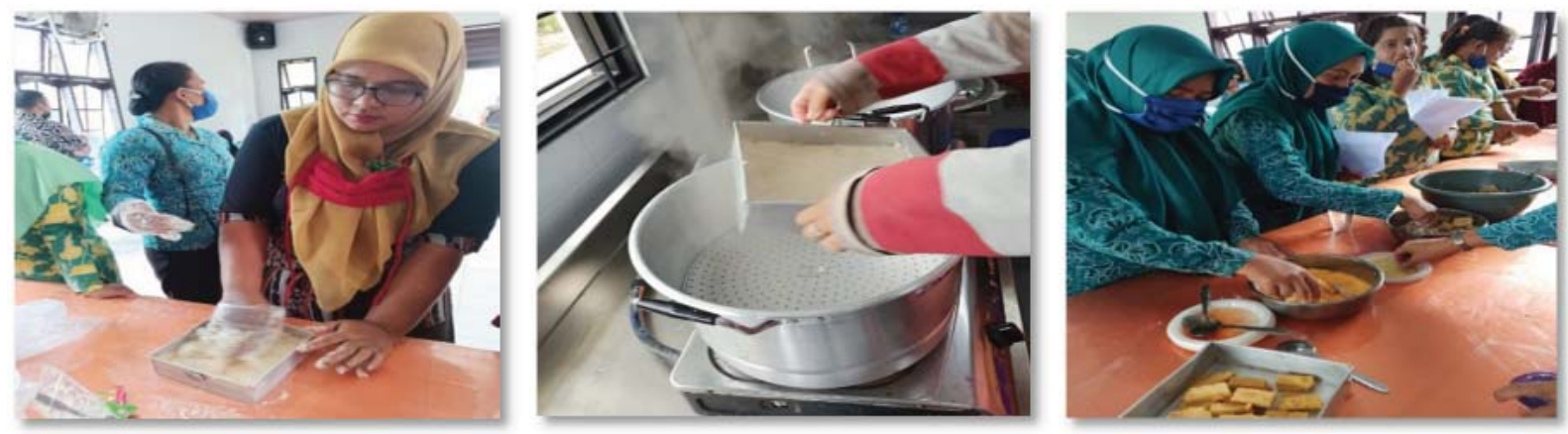

Gambar 9. Membuat adonan ke loyang dan mengukus adonan

Gambar 10. Proses akhir pembuatan nugget

\section{Penyajian Nugget Ikan Teter}

Penyajian nugget dapat dilakukan dengan menggoreng nugget dengan minyak panas hingga tepung panir dan nugget semakin menyatu. Proses penggorengan dilakukan seperti proses penggorengan umumnya. Adapun hasil Nugget Ikan Teter yang telah di goreng disajikan pada Gambar 11.

\section{Proses pengemasan Nugget Ikan Teter}

Selain diberikan pelatihan dalam pembuatan Nugget Ikan Teter, ibu-ibu PKK di Kecamatan Sorkam, Kabupaten Tapanuli Tengah juga diberikan penjelasan bagaimana cara mengkemas produk yang dihasilkan sehingga dapat disimpan dalam bentuk beku dan bisa dinikmati dalam jangka panjang. Hasil dari produk yang dihasilkan terlihat pada Gambar 12.
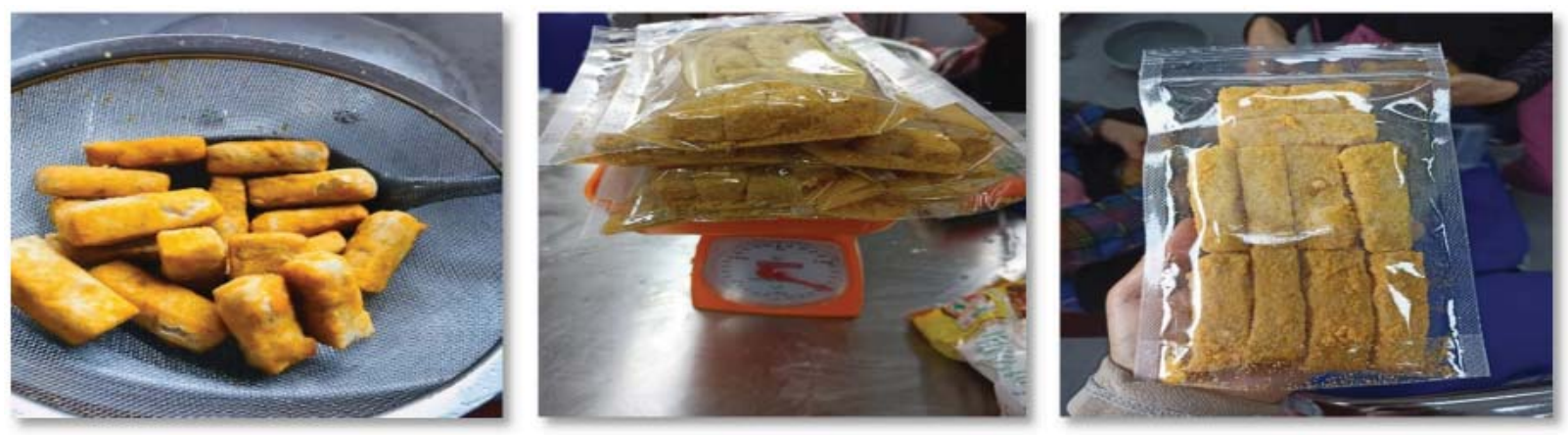

Gambar 11. Hasil nugget yang telah digoreng

Gambar 12. Pengemasan produk Nugget Ikan Teter

\section{Penutupan}

Adapun tahap terakhir kegiatan pengabdian kepada masyarakat ini yaitu penutupan. Tim PkM memberikan cenderamata kepada ibu-ibu PKK di Kecamatan Sorkam, Kabupaten Tapanuli Tengah kemudian dilakukan foto bersama sebagai dokumentasi akhir dari kegiatan PkM. Adapun kegiatan penutupan disajikan pada Gambar 13. 
ABDIMAS: Jurnal Pengabdian Masyarakat Universitas Merdeka Malang Volume 7, No 1, February 2022: 103-112
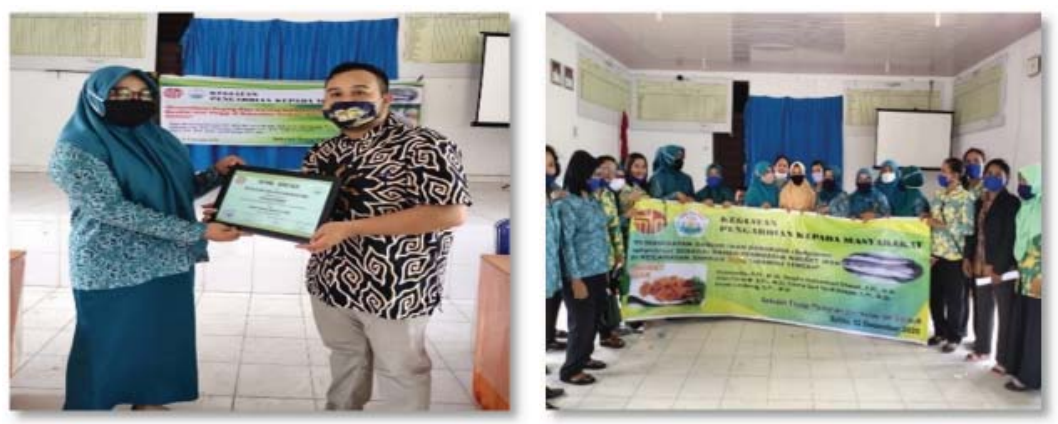

Gambar 13. Proses penutupan PkM

Kegiatan pengabdian kepada masyarakat yang dilakukan berjalan dengan lancar. Seluruh peserta merasa antusias terhadap kegiatan yang dilaksanakan. Setelah mengikuti kegiatan ini, ibu-ibu PKK di Kecamatan Sorkam memahami pentingnya membuat makanan hasil olahan perikanan mengingat kebanyakan latar belakang dari pekerjaan suami mereka adalah nelayan. Ibu-ibu PKK sudah mampu membuat 1 produk olahan berbahan ikan yaitu nugget. Selain mampu membuat hasil olahan dari daging Ikan Teter, ibu-ibu PKK juga mampu mengemas nugget dengan baik.

Kegiatan PkM ini merupakan kegiatan perdana yang dilaksanakan oleh Sekolah Tinggi Perikanan dan Kelautan Matauli di Kecamatan Sorkam untuk mengenalkan produk olahan hasil perikanan yang dapat dijadikan kedepannya sebagai penghasilan. Kegiatan ini akan terus dilaksanakan ke depannya sehingga yang menjadi target untuk terciptanya oleh-oleh khas Tapanuli Tengah.

Adapun luaran yang dicapai pada kegiatan ini adalah sebagai berikut: (1) Target peserta kegiatan pengabdian yang dilakukan telah ditetapkan ibu-ibu PKK di Kecamatan Sorkam, Kabupaten Tapanuli Tengah di mana dari tingkat kehadiran peserta dalam kegiatan PkM dibatasi karena pelaksanaan PkM dijalankan sesuai protokol COVID-19, kemampuan peserta dalam memahami materi dan praktik pembuatan nugget secara langsung juga sudah baik dan kemampuan tim PkM dalam menyajikan materi sudah baik; (2) Kemampuan pemahaman peserta akan materi yang disampaikan terlihat dari pertanyaan-pertanyaan yang disampaikan pada sesi diskusi. Dimana peserta mampu menyerap dan menanggapi materi yang disampaikan oleh tim PkM yang berhubungan dengan pembuatan Nugget Ikan Teter; (3) Setiap peserta menunjukkan keingintahuannya mengenai cara pembuatan nugget sampai pengemasan; (4) PkM ini memberikan pemahaman kepada peserta, bagaimana peran Perguruan Tinggi dalam penerapan ilmu secara langsung kepada masyarakat; (5) PkM ini juga memberikan pengetahuan kepada peserta mengenai bahan dan alat yang digunakan dalam pembuatan nugget tergolong murah dan mudah ditemukan di wilayah Tapanuli Tengah, khususnya di Kecamatan Sorkam; (6) Setelah adanya kegiatan ini, berdasarkan hasil survei ke lapangan yang dilakukan pada bulan Januari 2021, beberapa ibu-ibu PKK sudah mulai menerapkan pembuatan Nugget Ikan baik untuk konsumsi keluarga maupun dijual di sekitaran rumah.

Selain keberhasilan yang dicapai, PkM ini juga memiliki faktor penghambat. Adapun faktor penghambat terlaksananya PkM ini adalah keterbatasan jumlah peserta yang hadir, karena PkM ini dilaksanakan pada masa pandemi COVID-19, sehingga pelaksanaannya harus mengikuti protokol kesehatan.

\section{SIMPULAN DAN SARAN}

Sekolah Tinggi Perikanan dan Kelautan Matauli telah melaksanakan kegiatan pengabdian masyarakat dengan tema pemanfaatan daging Ikan Barakuda sebagai bahan pembuatan Nugget Ikan. Ibu-ibu 
PKK di Kecamatan Sorkam, Kabupaten Tapanuli Tengah sangat antusias dengan adanya kegiatan ini. Kegiatan ini dilakukan untuk memberikan informasi dan pelatihan kepada Ibu-ibu PKK di Kecamatan Sorkam, Kabupaten Tapanuli Tengah tentang manfaat Ikan Barakuda dan cara mengolahnya sebagai bahan olahan nugget.

Perlu adanya sosialisasi serta promosi mengenai adanya program ini, sehingga peserta tidak hanya berasal dari ibu-ibu PKK di Kecamatan Sorkam namun juga ibu-ibu PKK di kecamatan lainnya yang ada di Kabupaten Tapanuli Tengah. Diharapkan kegiatan ini akan terus dilakukan dengan melihat berbagai potensi ikan di wilayah Tapanuli Tengah yang kedepannya dapat menjadi UMKM dan menjadi produk oleh-oleh wilayah Tapanuli Tengah.

\section{DAFTAR PUSTAKA}

Aziza, T., Affandi D. R \& Manuhara G. J. (2015). Bakso Ikan Tongkol (Euthynnus affinis) dengan filler Tepung Gembili sebagai fortifikan inulin. Jurnal Teknologi Hasil Pertanian, 8(2), 77-83. https://doi.org/10.20961/jthp.v0i0.12894

Direktorat Jenderal Perikanan Tangkap. (2003). Kandungan gizi ikan. Departemen Kelautan dan Perikanan RI.

Dinas Perikanan dan Kelautan Tapanuli Tengah. (2021). Potensi perikanan dan kelautan. Dinas Perikanan dan Kelautan Tapanuli Tengah.

Fatmawati, F., Aqmal, A., \& Rampeng, R. (2018). Pengaruh konsentrasi Rumput Laut (Kappa phycusalvarezii) terhadap tekstur Bakso Ikan Alu-Alu (Sphyraenagenie). Ecosystem, 18(1), 10391047.

Genesa, J., Sukendar, N. K., \& Regia, S. (2018). Studi pembuatan nugget fungsional dari Ikan Cakalang (Katsuwonus pelamis L.) dengan ekstrak Buah Mengkudu (Morinda citrifolia L.). Canrea Journal: Food Technology, Nutritions, and Culinary Journal, 1(1). 69-77. https://doi.org/10.20956/canrea.v1i1.24

If'all, I., Gobel, M., Fahmi, F., \& Pakaya, I. (2018). Mutu kimia dan organoleptik Nugget Ikan Tuna dengan penambahan berbagai kombinasi Tepung Wortel. Jurnal Agroindustri Halal, 4(1), 53-59. https://doi.org/10.30997/jah.v4i1.1128

Laksono, U. T., Suprihatin, S., Nurhayati, T., \& Romli, M. (2019). Enhancement of textural quality from Daggertooth Pike Conger Fish surimi with Sodium Tripolyphosphate and Transglutaminase activator. Jurnal Pengolahan Hasil Perikanan Indonesia, 22(2), 198-208.

Lukman, I., Nurul, H., \& Noryati, I. (2009). Physicochemical and sensory properties of commercial chicken nuggets. Asian Journal of Food and Agro-Industry, 2(2), 171-180.

Purwandari, L. Y., Darmanto, Y. S., \& Wijayanti, I. (2014). Pengaruh penambahan egg white powder terhadap kualitas gel surimi pada beberapa jenis ikan laut. Jurnal Pengolahan dan Bioteknologi Hasil Perikanan, 3(2), 106-113.

Rieuwpassa, F. J. (2016). Karakteristik kimia dan nilai organoleptik Nugget Ikan Tuna dengan subtitusi Tepung Sagu. Jurnal Ilmiah Tindalung, 2(2), 103-111. https://doi.org/10.5281/jit.v2i2.92

Rijal, M. (2016). Diversifikasi produk olahan ikan bagi ibu-ibu nelayan di Dusun Mamua Kabupaten Maluku Tengah. Biosel: Biology Science and Education, 6(2), 159-170.

http://dx.doi.org/10.33477/bs.v6i2.383 
ABDIMAS: Jurnal Pengabdian Masyarakat Universitas Merdeka Malang Volume 7, No 1, February 2022: 103-112

Sali, F., Asnani, A., \& Suwarjoyowirayatno, S. (2020). Mutu kimia dan organoleptik Nugget Ikan Barakuda (Sphyraena jello) dengan substitusi Tepung Tapioka dan Tepung Wortel (Daucus carota L.). Jurnal Fish Protech, 3(1), 1-8.

Shalfiah, R. (2013). Peran Pemberdayaan dan Kesejahteraan Keluarga (PKK) dalam mendukung program-program pemerintah Kota Bontang. eJournal Ilmu Pemerintahan, 1(3), 975-984.

Tina, N., Nurul, H., \& Ruzita, A. (2010). Surimi-like material: Challenges and prospects. International Food Research Journal, 17(3), 509-517.

Utiarahman, G., Harmain, R. M., \& Yusuf, N. (2013). Karakteristik kimia dan organoleptik nugget ikan layang (Decapterus sp.) yang disubtitusi dengan tepung ubi jalar putih (Ipomea batatas L). The NIKe Journal, 1(3). https://doi.org/10.37905/.v1i3.1232

Wahdan, M. F. (2010). Karakteristik fisika kimia surimi dari daging lumat ikan Hasil Tangkap Sampingan (HTS) Pukat Udang Skripsi. Universitas Institut Pertanian Bogor.

Yulianti, Y., \& Mutia, K. (2018). Analisis kadar protein dan tingkat kesukaan Nugget Ikan Gabus dengan penambahan Tepung Wortel. Gorontalo Agriculture Technology Journal, 1(1), 37-41.

https://doi.org/10.32662/gatj.v1i1.165 